Ann. Biol. anim. Bioch. Biophys., 1979, 19 (6), 1757-1770.

\title{
Measurement of the rate of cholesterol synthesis in various organs of the rat in vivo.
}

\author{
par T. MAGOT, F. CHEVALLIER
}

\author{
Laboratoire de Physiologie de lo Nutrition, \\ Equipe de Recherche Associée au CNRS (ERA 415) \\ Formation de Recherche INSERM (FRA no 41) \\ Université de Paris Sud-Bâtiment 447 \\ 91405 Orsay Cedex, France.
}

Summary. A method to measure the absolute values of the rate of cholesterol synthesis in vivo in the organs of the rat has been described. Adult male rats were intravenously infused for 3.5, 6 and $10 \mathrm{~h}$ with sodium 1-14(C)-acetate and the specific activity of expired $\mathrm{CO}_{2}$ was recorded during the experiment. Sterol radioactivities were measured in plasma, lipoproteins and in various organs, the radioactivities in each organ being corrected for cholesterol transfer. The rate of cholesterol synthesis in the intact rat and in each organ was calculated from the radioactivities of the sterols synthesized, that of the acetyl CoA metabolized and the rate of acetyl CoA utilization. The validity of the calculation has been discussed. The results showed that the intestine was the major site of cholesterol biosynthesis (about 50 p. 100). The participation of other tissues, such as skin $(20$ p. 100), liver (less than 10 p. 100), kidneys, bone marrow, colon and stomach (2-3 p. 100), was less important, whereas that of all the other organs, particularly the adrenals, was very slight $(0.2-1$ p. 100).

\section{Introduction.}

The rate of cholesterol synthesis in various tissues has been previously reported. Measurement in vitro (Dietschy and Siperstein, 1967 ; Dietschy and Wilson, 1968 ; Srere et al., 1950) probably led to erroneous results since naturally occurring regulatory mechanisms were suppressed in those conditions (Chevallier and Mathé, 1976). On the other hand, during experiments in vivo the measurement of labeled precursor incorporation into sterols (Jansen et al., 1970 ; Popjak and Beeckmans, 1950 ; Schwenk ef al., 1955 ; Van Bruggen ef al., 1953), without estimating the contribution of cholesterol transfer between the plasma and the organs to the labeling, may have also resulted in some cases in erroneous values. In these conditions, the liver was generally believed to be the major source of cholesterol biosynthesis (Kritchevsky, 1958).

Permanent cholesterol transfer between the plasma and the organs, and viceversa, explains why a part of organ cholesterol comes from the plasma and the cholesterol synthesized in sifu in the organs is released into the plasma. Thus, organ cholesterol has a double origin : in situ synthesis and the plasma. Generally, most of the 
organ cholesterol is of plasmatic origin (Chevallier, 1967). When a labeled precursor is used in vivo, cholesterol transfer first involves the release of labeled cholesterol (biosynthesized in an organ) into the plasma, and later the transfer of the plasma cholesterol, thus labeled, into all the organs. Consequently, preliminary studies on cholesterol transfer from the plasma to the organs are prerequisite to knowing the fraction of the labeling corresponding to in situ synthesis. In our studies on the rat, we thus used an isotopic equilibrium method to identify the organs which biosynthesized cholesterol (intestine, colon, bone marrow, skin, kidneys, testis, brain) (Chevallier, 1956). The proportion of cholesterol actually synthesized by an organ has been determined using the same method : $15 \mathrm{p} .100$ for the testis and intestine ( $2.6 \mathrm{mg}$ for the infestine) and 1 p. 100 for the liver $(0.3 \mathrm{mg})$ (Chevallier et al., 1968). The purpose of the present work was to define the rate of cholesterol synthesis in various organs of the rat.

The measurement of cholesterol synthesis rate in vivo implies the use of a labeled precursor during short-term experiments. The amount of cholesterol transferred from the plasma into each organ has already been measured by such experiments involving the infusion of red cells (« red-cell » experiments) or plasma (" plasma » experiments) containing labeled cholesterol (Chevallier ef al., 1971 ; Giraud et al., 1976). In the present study, a similar procedure was adopted which involved infusing rats with $1{ }^{14}(C)$-acetate solutions (《 acetate » experiments). The kinetics of the changes in the specific activities of free and esterified plasma cholesterol during the "acetate " experiments were similar to those obtained in the « red-cell 》 experiments. We could thus calculate by the transfer the amount of radioactivity originating from the plasma, and deduce that of the sterols which were synthesized and remained in situ. The rate of cholesterol synthesis in the intact animal and in each organ was determined from these values. The method offers the advantage of furnishing absolute rates of synthesis, whereas in the literature they are usually relative (Jansen ef al., 1970 ; Popjak and Beeckmans, 1950 ; Schwank et al., 1955 ; Van Bruggen et al., 1953). The intestine again appeared to be the major site of cholesterol biosynthesis in the adult male rat. A preliminary report of these results has been published (Chevallier and Magot, 1975).

\section{Material and methods.}

1. Experimental procedure. - Adult male Wistar rats weighing $330 \pm 5 \mathrm{~g}$ were used. They were maintained on a semi-synthetic diet after weaning (D'Hollander and Chevallier, 1969). Eight days before the experiment, they were fed a cholesterolfree diet (Chevallier et al., 1968). A catheter (PE 50 Intramedic polyethylene tubing) was introduced into a branch of the jugular vein under nembutal anesthesia $(0.12 \mathrm{ml} /$ $100 \mathrm{~g}$ body weight) 3 days before the experiment, and was placed under the back skin to emerge at the dorsal part of the neck ; its end was flame-sealed. The catheterized rats could move normally in their individual cages. Those showing a perturbed dietary intake were excluded from the experiment. In each trial, an isotonic saline solution of sodium 1-14(C)-acetate was intravenously infused at a constant rate $(0.2 \mathrm{ml} / \mathrm{h})$ with a Braun perfusor. The metabolism cages in which the animals were placed permitted continuous measurement of expired ${ }^{14} \mathrm{CO}_{2}$ (Chevallier et al., 1962) ; the expe- 
riments lasted 3.5 (5 rats), 6 (5 rats) or 10 (7 rats) hours. Whatever the experimental duration, the rats were always killed between noon and 2 p.m. by intraaortic puncture, and the cardiovascular system washed 2 or 3 times with isotonic saline. Seventeen organs or tissue fragments were removed and placed in ethanol. The heparinized blood was centrifuged (2,200 $\mathrm{g}$ at $4{ }^{\circ} \mathrm{C}$ for $20 \mathrm{~min}$ ), and the plasma and red cells were recovered. The different plasma lipoprotein classes were isolated by ultracentrifugation (Giraud-D'Hollander ef al., 1976) : VLDL (very low density lipoproteins) $d<$ 1.006 ; LDL (low density lipoproteins) $1.006<d<1.040$; HDL (high density lipoproteins) $d>1.063$.

The characteristics of acetyl CoA turnover were determined in 8 rats by decay curve analysis of the specific activity of expired $\mathrm{CO}_{2}$ after a single subcutaneous injection of trace amounts of $1-14(C)$-acetate $(50-200 \mu \mathrm{Ci}$ in $0.1 \mathrm{ml}$ of saline solution).

2. Chemical and isotopic methods. - Free and esterified cholesterol was separated, and its specific activities were measured as previously described (Giraud-D'Hollander ef al., 1976). An additional precaution was taken since the present experiments required the administration of a labeled cholesterol precursor: the free sterols obtained by silicic acid column chromatography were saponified (as esterified sterols) in order to eliminate non-sterolic labeled compounds (Chevallier and Rodriques Branco, 1963). The sterol radioactivity of an organ was calculated by multiplying the sterol specific activity by the mean sterol content of that organ, previously determined in rats of the same strain, age and weight and fed the same diet (D'Hollander and Chevallier, 1969).

3. Calculation of cholesterol synthesis rates.

In the intact rat. Acetyl CoA metabolism in the intact rat is shown is figure 1. Acetyl CoA molecules were used in three kinds of metabolisms : cholesterol biosynthesis (way S), degradation into $\mathrm{CO}_{2}$ (way $\mathrm{C}$ ), and various other metabolisms (way I). The radioactivity of the infused acetate was distributed into the three ways $R_{3}, R_{C}$ and $R_{I}$,

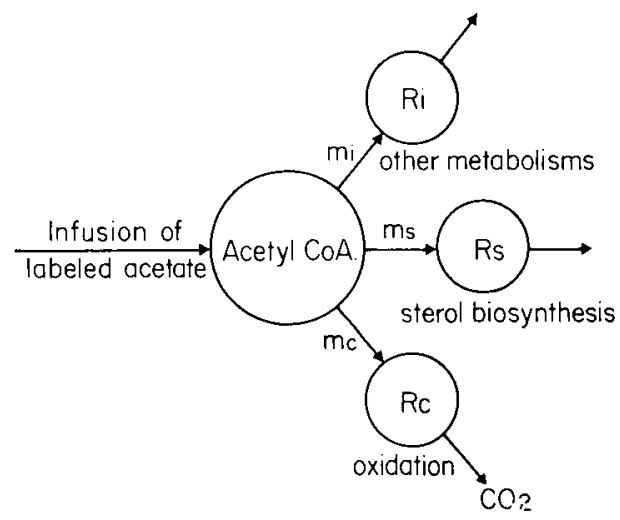

FIG. 1. - Schematic representation of acetyl CoA metabolism in an intact rat. The radioactivity of perfused acetate is distributed into 3 kinds of metabolism : cholesterol biosynthesis (S way), degradation into $\mathrm{CO}_{2}$ ( $\mathrm{C}$ way) and the others (I ways); $\mathrm{m}_{\mathrm{s}}, \mathrm{m}_{\mathrm{C}}$ and $\mathrm{m}_{\mathrm{I}}$ are the rates of these processes and $R_{S}, R_{C}$ and $R_{I}$ the radioactivities distributed in the 3 metabolic pathways. 
depending on their utilization rate $\left(m_{S}, m_{C}\right.$, and $m_{I}$, respectively). The rate $\left(m_{C}\right)$ of overall acetyl CoA utilization was defined by the sum $m_{\mathrm{s}}+\mathrm{m}_{\mathrm{C}}+\mathrm{m}_{\mathrm{I}}$. The calculation was based on the following three conditions : the acetyl CoA pool was homogeneous, the sterol radioactivity eliminated from the system was negligible, and there was no new formation of labeled acetyl CoA from the labeled compounds $R_{I}$ during the experimental time ; in other words, $m_{I}$ was considered as isotopically irreversible.

Therefore, the calculation of the synthesis rate was based on the following : at each time, the ratio of synthesized sterol radioactivity to that of metabolized acetyl CoA was equal to the proportion between the amount of acetyl CoA used in sterol synthesis and that in its overall metabolic pathway:

$$
\frac{m_{\mathrm{S}}}{\mathrm{m}_{\mathrm{U}}}=\frac{\mathrm{R}_{\mathrm{s}}}{\mathrm{R}_{\mathrm{U}}}
$$

$\mathrm{m}_{\mathrm{s}}=$ rate of acetyl CoA utilization for cholesterol synthesis (mole of acetyl CoA/h) : expressed in milligrams of cholesterol synthesized per hour

$\mathrm{m}_{\mathrm{U}}=$ rate of acetyl CoA utilization for overall metabolic pathways in the intact rat : furnished by experiments involving $1 \mathbf{1}^{14}(\mathrm{C})$-acetate injection

$\mathrm{R}_{\mathrm{S}}=$ radioactivity of sterols synthesized in the rat

$R_{U}=$ radioactivity of metabolized acetyl CoA at the time the rats were killed, calculated as the difference between the administered radioactivity $\left(R_{0-t}\right)$ and that of the acetyl CoA still unused at that time. The latter value was calculated by multiplying the acetyl CoA pool size (M) by its specific activify. According to Pascaud (1963) and taking into account the diet composition, we considered that 75 p. 100 of the $\mathrm{CO}_{2}$ molecules were provided by acetyl CoA degradation. Since acetyl CoA was labeled only on carbon I, its specific activity $(r)$ was given by the following relation :

$$
r_{\text {acetyl } \mathrm{CoA}}=2 \times \frac{4}{3} \mathrm{r}_{\mathrm{CO}_{2}}
$$

In each organ. If the pool of acetyl CoA was homogeneous in the intact rat, the relationship (1) could be applied to each organ

$$
\frac{\mathrm{m}_{\mathrm{Si}}}{\mathrm{m}_{\mathrm{U}}}=\frac{\mathrm{R}_{\mathrm{Si}}}{\mathrm{R}_{\mathrm{U}}}
$$

where $m_{S i}$ and $R_{S i}$ are, respectively the rate of cholesterol synthesis and the activity of the sterol synthesized in the organ. The relationships (1) and (3) gave

$$
\frac{m_{S i}}{m_{S}}=\frac{R_{S i}}{R_{S}}
$$

Therefore, the participation of an organ in cholesterol synthesis in the intact rat was equal to the ratio of the radioactivity due to synthesis in that organ to that found in the intact rat.

Before applying the relationship (4), it was necessary to subtract from the free and esterified sterol radioactivities $\left(R_{F}\right.$ and $\left.R_{E}\right)$ that of transferred cholesterol, i.e. coming from the plasma, either as a free $\left(R_{P F}\right)$ or an esterified $\left(R_{P E}\right)$ fraction. When the time-course of the specific activity of free and esterified plasma sterols during 
the « red-cell 》 experiments was considered as similar to that obtained during the « acetate » experiments, the following relationship was applied to free cholesterol

$$
\mathrm{R}_{\mathrm{PF}}=\mathrm{R}_{\mathrm{PF}}^{\prime} \frac{\mathrm{r}_{\mathrm{PF}}}{r_{\mathrm{PF}}^{\prime}}
$$

where $R_{P F}^{\prime}$ and $R_{P F}$ are the radioactivities of the free plasma cholesterol in the " acetate 》 and the "red-cell 》 experiments, and $r_{P F}^{\prime}$ and $r_{P F}$ are the corresponding specific activities of free plasma cholesterol at the same time in these two experiments. Data from the " red-cell » experiments have been previously published (GiraudD'Hollander ef al., 1976). This relationship was applied to the free and esterified cholesterol in each organ. The radioactivity of the sterols synthesized and remaining in situ $\left(R_{\mathrm{SF}}=\mathrm{R}_{\mathrm{F}}-\mathrm{R}_{\mathrm{PF}}\right.$ and $\mathrm{R}_{\mathrm{SE}}=\mathrm{R}_{\mathrm{E}}-\mathrm{R}_{\mathrm{PE}}$ ) was determined. The rates $\mathrm{m}_{\mathrm{SF}}$ and $m_{S E}$ were calculated with the relationship (4). The rate of synthesis in each organ was initially defined by the sum $\mathrm{m}_{\mathrm{SF}}+\mathrm{m}_{\mathrm{SE}}$.

\section{Results.}

1. - Specific expired $\mathrm{CO}_{2}$ activities.

${ }^{1-14}(C)$-acetate injection experiments. - The specific activity curve of ${ }^{14} \mathrm{CO}_{2}$ expired by a rat after a single injection of $1-{ }^{14} \mathrm{C}$-acetate was decomposed into two exponential functions $\left(K=1.37 \pm 0.05 h^{-1}\right.$ and $\left.K^{\prime}=0.13 \pm 0.02 h^{-1}\right)$ (fig. 2). The fast exponen-

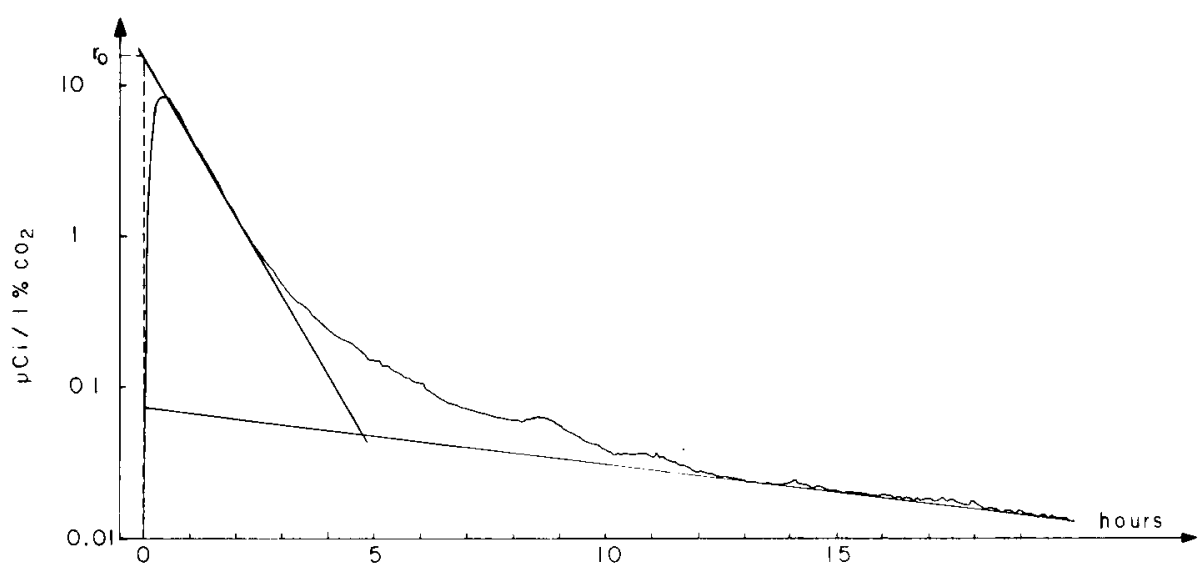

FIG. 2. - Specific activity of expired $\mathrm{CO}_{2}$ in a rat after a single injection of $\mathrm{k-14}(\mathrm{C})$ acetate $(200 \mu \mathrm{Ci})$. $\mathrm{r}^{0}$ : extrapolated specific activity at zero time.

tial corresponded to overall acetyl CoA utilization. The ratio of the value of injected acetate radioactivity to specific acetyl COA activity, obtained by extrapolating this exponential to zero time, furnished the pool size $(M)$ of acetyl CoA. The furnover rate of acetyl CoA $\left(m_{U}\right)$ was calculated from $m_{U}=K$. M. The values of $M$ and $m_{U}$ obtained by this method were $3.06 \pm 0.3 \mathrm{mM}$ and $4.2 \pm 0.6 \mathrm{mM} / \mathrm{h}$. 
1-14(C)-acetate infusion experiments. - The specific activity of $\mathrm{CO}_{2}$ expired by a rat during $1-{ }^{11}(\mathrm{C})$-acetate infusion experimentation increased, reaching an equilibrium value after $3 \mathrm{~h}$ of infusion (fig. 3). The measured equilibrium value was proportional

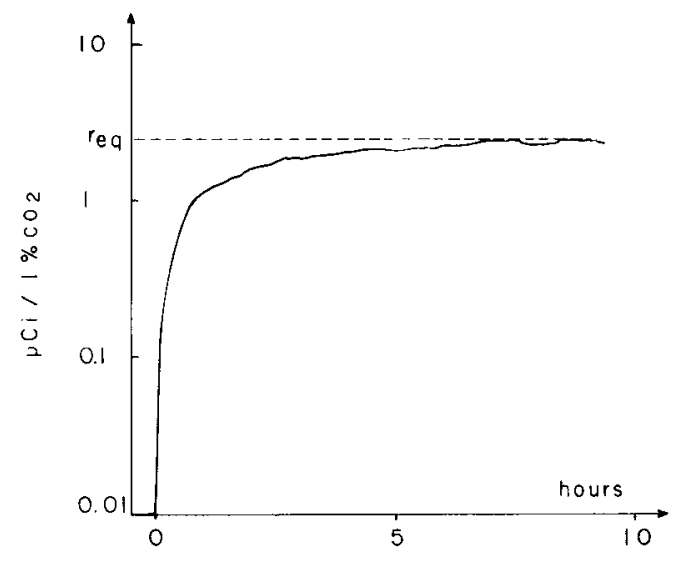

FIG. 3. - Specific activity of expired $\mathrm{CO}_{2}$ in a rat during a $\mathrm{I}^{14}(\mathrm{C})$ ocetate infusion experiment $(50 \mu \mathrm{Ci} / \mathrm{hr}) \mathrm{r}_{\mathrm{eq}}$ : specifie activity at equilibrium.

to the rate of infused radioactivity. An equilibrium value of $1 \mu \mathrm{Ci} / 1$ p. $100 \mathrm{CO}_{2}$ was obtained by $1{ }^{14}(C)$-acetale infusion at a mean rate of $24.4 \pm 2.0 \mu \mathrm{Ci} / \mathrm{h}$. Since that acetate infusion rate was variable in the different experiments, the crude radioactivities were corrected to the above specific equilibrium activity of ${ }^{14} \mathrm{CO}_{2}$. Under these conditions, the administered activities $\left(R_{O-t}\right)$ were $188 \pm 22.10^{6}, 322 \pm 37.10^{6}$ and $537 \pm 62.10^{6} \mathrm{dpm}$ for 3.5, 6 and 10-hour infusion times, respectively. animal.

2. - Cholesterol radioactivity and specific activity in the organs, plasma and infact

Specific activities of free and esterified plasma cholesterol increased with time (fig. 4), showing the transfer of synthesized organ cholesterol to the plasma. The spe-

FIG. 4. - Mean values of specific activities (dpm/mg) of free (F) and esterified (E) plasma cholesterol in a rat during $1-14(C)$ acetate infusion $(24.4 \mu \mathrm{Ci} / \mathrm{hr})$.

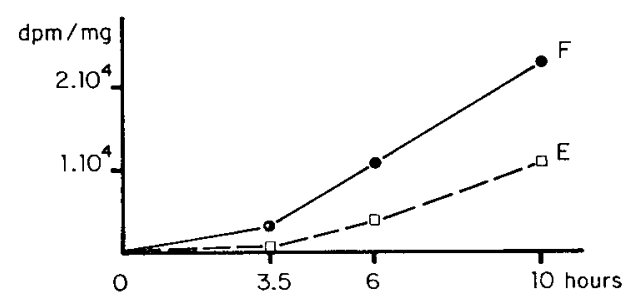

cific activities of the free and esterified cholesterol in lipoproteins were expressed as the percent of that of free plasma cholesterol (table 1). HDL cholesterol labeling was nearly identical in the " acetate » and the " red-cell » experiments; that of LDL was higher in the former. This difference was greater in the VLDL, especially for esterified cholesterol (Giraud-D'Hollander et al., 1976). 
The radioactivities of the free and esterified cholesterol $\left(R_{F}\right.$ and $\left.R_{E}\right)$ of each organ and of the intact animal were calculated for the three experimental durations,

\section{TABLE 1}

Mean values ( \pm SEM) of the specific activities of free (F) and esterified (E) cholesterol in the different lipoprotein classes of a rat affer $3.5,6$ or 10 hrs infusion with 1-14(C) acetate, expressed as a percent of the specific activity of free plasma cholesterol

\begin{tabular}{|c|c|c|c|c|}
\hline & & \multicolumn{3}{|c|}{ Experimental duration (hrs) } \\
\hline & & 3.5 & 6 & 10 \\
\hline Plasma & $\begin{array}{l}F \ldots \ldots \ldots \ldots \ldots \\
E\end{array}$ & $\begin{array}{l}100 \\
27 \pm 1\end{array}$ & $\begin{array}{l}100 \\
38 \pm 2\end{array}$ & $\begin{array}{l}100 \\
45 \pm 5\end{array}$ \\
\hline Red cells & $\ldots$ & $30 \pm 1$ & $43 \pm 2$ & $49 \pm 6$ \\
\hline HDL & $\begin{array}{l}\mathrm{F} \ldots \ldots \ldots \ldots \\
\mathrm{E} \ldots \ldots \ldots \ldots\end{array}$ & $\begin{array}{l}67 \pm 5 \\
23 \pm 1\end{array}$ & $\begin{array}{l}91 \pm 2 \\
36 \pm 1\end{array}$ & $\begin{array}{l}79 \pm 6 \\
47 \pm 8\end{array}$ \\
\hline LDL & $\begin{array}{l}F, \ldots \ldots \cdots \\
E \ldots \ldots \cdots \cdots\end{array}$ & $\begin{array}{l}177 \pm 30 \\
106 \pm 11\end{array}$ & $\begin{array}{r}113 \pm 1 \\
83 \pm 8\end{array}$ & $\begin{array}{l}136 \pm 14 \\
161 \pm 50\end{array}$ \\
\hline VLDL & 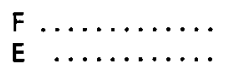 & $\begin{array}{l}192 \pm 45 \\
332 \pm 106\end{array}$ & $\begin{array}{l}86 \pm 1 \\
78 \pm 2\end{array}$ & $\begin{array}{l}92 \pm 6 \\
89 \pm 29\end{array}$ \\
\hline
\end{tabular}

but are presented for only 3.5-hour infusion (table 2). The radioactivity values of free sterols, transferred from the plasma $\left(R_{P F}\right)$ and synthesized in situ $\left(R_{S F}=R_{F}\right.$ $R_{P F}$ ) in each organ, are shown in the same table as those of esterified cholesterol $\left(R_{\mathrm{PE}}\right.$ and $\mathrm{R}_{\mathrm{SE}}$ ). The contribution of free and esterified cholesterol transfer was especially important in liver, muscle, lung, adipose tissue and adrenals. In the intestine the radioactivity of free biosynthesized cholesterol $\left(\mathrm{R}_{\mathrm{SF}}\right)$ nearly reached an equilibrium value after 10 hours of infusion (fig. 5), suggesting that this cholesterol turned over several times. The $\mathrm{R}_{\mathrm{SF}}$ curve for the liver did not show such a clear result (fig. 5),

FIG. 5. - Time course of the appearance of radioactivity $(\mathrm{dpm})$ in sterols synthesized by the rat infestine. and liver, and remaining in situ in the free form $\left(R_{S F}\right)$ during $1.14(C)$ acetate infusion $(24.4 \mu \mathrm{Ci} / \mathrm{hr})$.

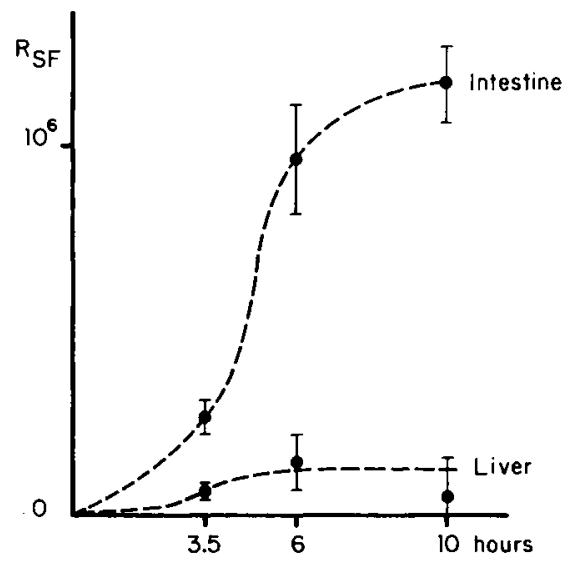




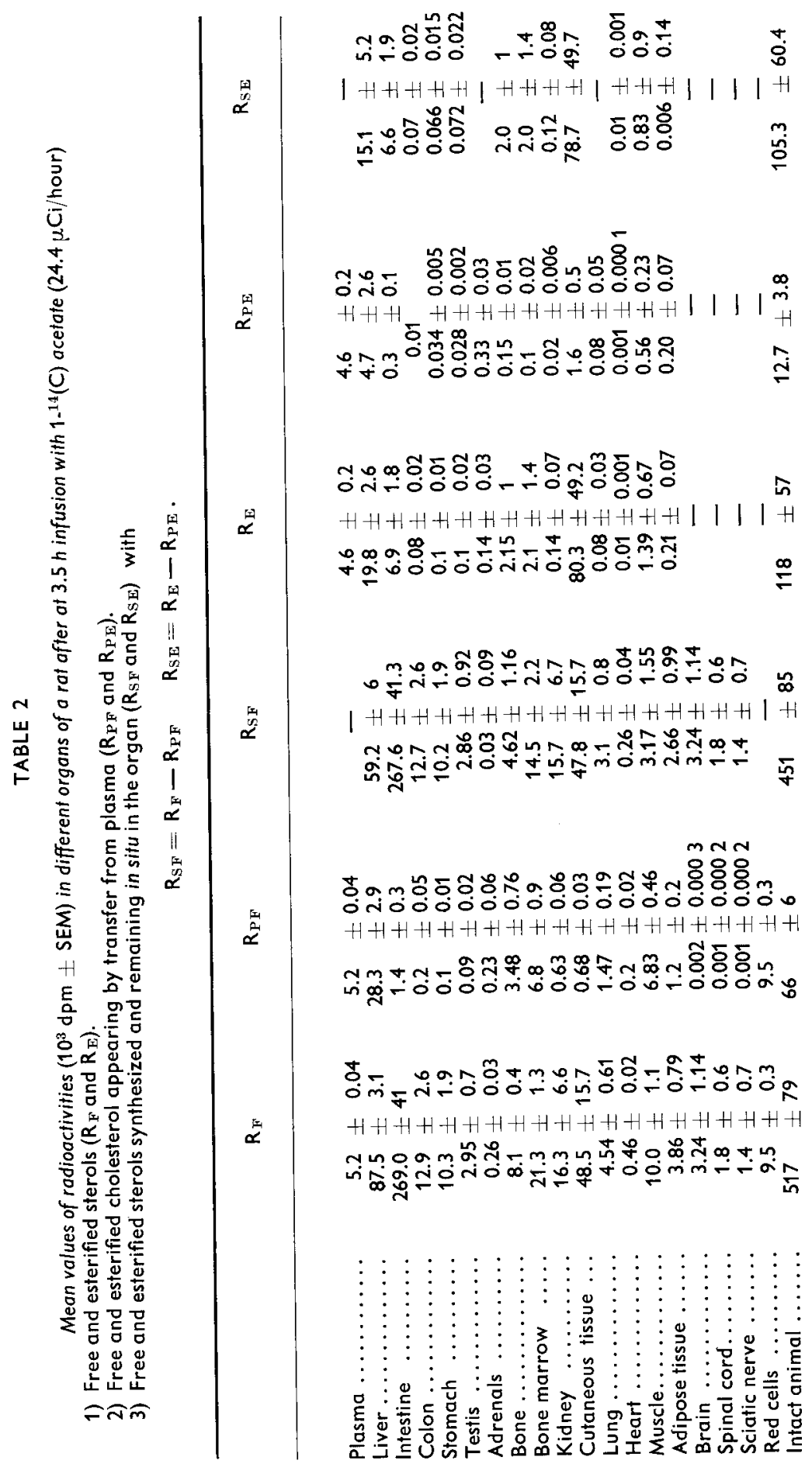




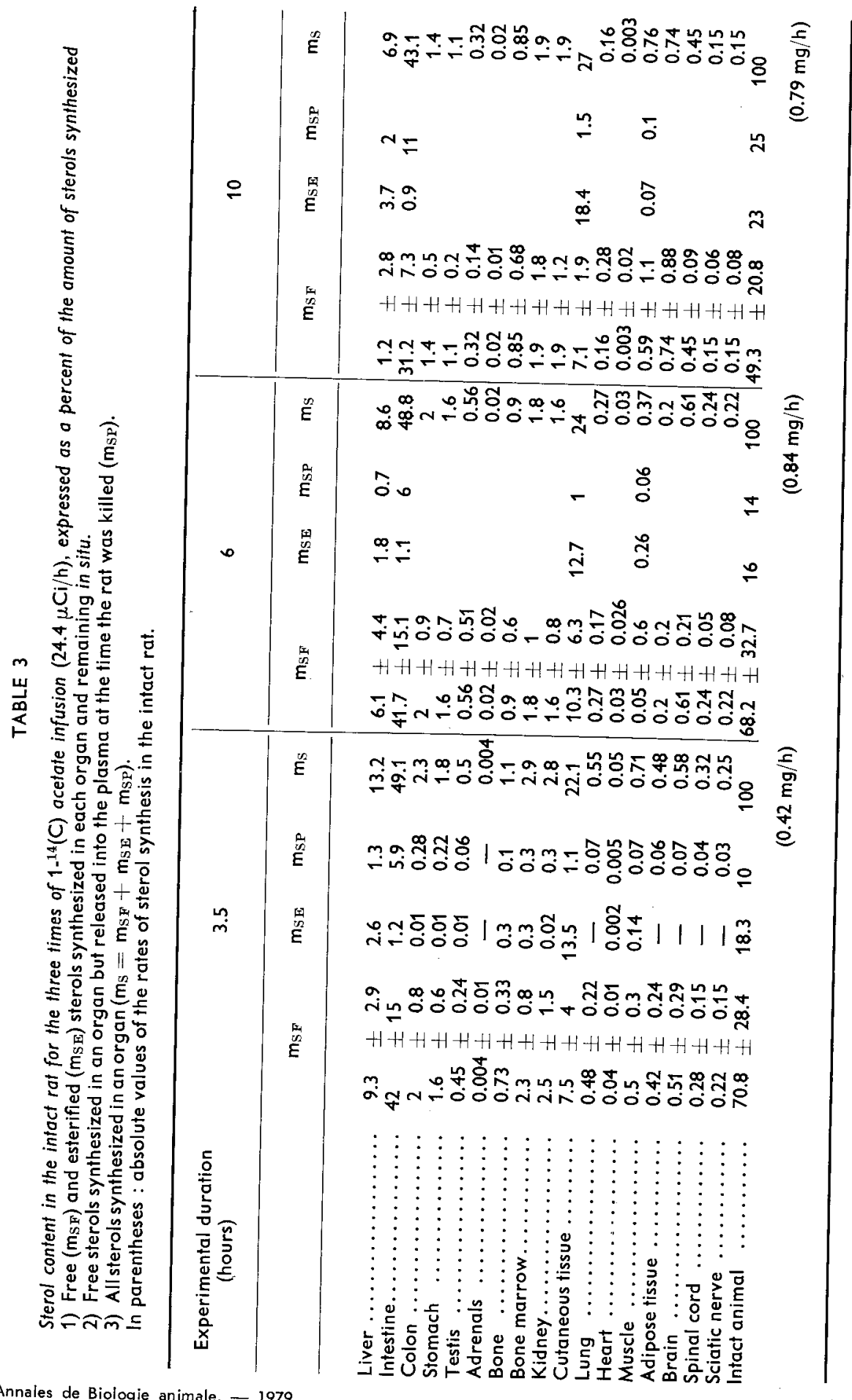


essentially because cholesterol transfer is rapid in that organ, so that every error of $R_{P F}$ strikingly affected the $R_{S F}$ values. The standard error value of figure 5 reflected this fact and increased with the experimental time; however, an equilibrium value was also probably reached in this organ.

\section{3. - Rate of cholesterol synthesis.}

The rate of cholesterol synthesis (relationship (1)) in the intact rat, calculated using the sum of free $\left(R_{F}\right)$ and esterified $\left(R_{E}\right)$ sterol radioactivities, was $0.42 \pm 0.13 \mathrm{mg} /$ $h, 0.84 \pm 0.26 \mathrm{mg} / \mathrm{h}$ and $0.79 \pm 0.19 \mathrm{mg} / \mathrm{h}$, respectively for the three infusion times.

The rate of synthesis (relationship (4)) of free $\left(m_{\mathrm{SF}}\right)$ and esterified $\left(\mathrm{m}_{\mathrm{SE}}\right)$ cholesterol was calculated for each organ (table 3 ). For $3.5 \mathrm{~h}$ of infusion, the intestine synthesized 43.2 p. 100 of the cholesterol as opposed to about 11.9 p. 100 for the liver. Moreover, very little synthesis was detected in the adrenals. At 6 and $10 \mathrm{~h}$ the values of the synthesis rates decreased for most organs, particularly for the liver and the intestine.

\section{Discussion.}

1. - Validity of the method.

A. - The use of equation (4) to calculate the rate of synthesis implied that the specific activity of acetyl COA and of synthesized cholesterol were each the same in all the organs. This specific activity was calculated in our experiments using two different methods. The specific activity of synthesized cholesterol in the liver and the intestine was first obtained from the ratio of the $R_{\mathrm{SF}}$ activity at equilibrium after $10 \mathrm{~h}$ of acetate infusion (fig. 5) to the mean amounts of synthesized cholesterol contained in the organs as estimated previously (Chevallier ef al., 1968). These amounts represented approximately $2.6 \mathrm{mg}$ for the intestine and $0.3 \mathrm{mg}$ for the liver. Therefore, specific synthesized cholesterol activities were about $3.8 .10^{5}$ in the intestine and $3.3 .10^{5} \mathrm{dpm} / \mathrm{mg}$ in the liver. Secondly this specific activity was calculated from that of expired $\mathrm{CO}_{2}$ at equilibrium ; its value was $3.10^{5} \mathrm{dpm} / \mathrm{mg}$. Thus, specific acetyl CoA activity was the same in the different organs, particularly in the liver and the intestine, although this assumption has recently been challenged (Fears and Morgan, 1976).

B. - The application of the relationship (1) was valid only if the compounds newly synthesized from the labeled acetyl CoA were not catabolized back into acetyl CoA during the experiment (fig. 1). Such a degradation (fatty acid catabolism, for example) probably resulted in the second slope $\left(K^{\prime}=0.13 \mathrm{~h}^{-1}\right)$ of the decrease of $\mathrm{CO}_{2}$ specific activity, but the specific activity of $\mathrm{Co}_{2}$ extrapolated to zero time did not exceed 1 p. 100 of the initial specific $\mathrm{CO}_{2}$ activity. Consequently, the metabolic pathways into which acetyl CoA was distributed were considered to be isotopically unidirectional during the experiment. The shorter the experiments, the lower the error due to the metabolic reappearance of labeled acetyl CoA.

C. - The calculation of the rate of cholesterol synthesis by the proposed method was only valid if the cholesterol synthesized in an organ or in the intact animal was 
not transferred elsewhere : into the plasma of an organ or into the external medium of the organism. Taking into account the elimination rates of cholesterol and bile acids (Chevallier and Lutton, 1966), the radioactivity elminated represented about only $0.4,0.5$ and 1 p. 100 of the total sterol radioactivity contained in the animal after $3.5,6$ and $10 \mathrm{hrs}$ of infusion.

For each organ, the relative amount of cholesterol transferred into the plasma increased with the time-course of the experiment. So, after 10,6 and 3.5 hrs the radioactivity of synthesized cholesterol transferred into the plasma (radioactivity of plasma cholesterol $+\Sigma R_{P F}$ of organs) reached 27,16 and 12 p. 100, respectively, of the sterol radioactivity of the intact animal (table 2). To correct the initial results, it was admitted that the flow of synthesized cholesterol from a given organ into the plasma $\left(m_{\mathrm{SP}}\right)$ was proportional to the rate of its synthesis in that organ. Thus, the radioactivity of synthesized cholesterol transferred into the plasma was distributed in the organs in proportion to their initially calculated synthesis rates $\left(m_{\mathrm{SF}}+\mathrm{m}_{\mathrm{SE}}\right.$; table 3$)$. The rate of synthesis $\left(m_{S}\right)$ in each organ was therefore defined by the sum $m_{\mathrm{SF}}+\mathrm{m}_{\mathrm{SE}}+$ $\mathrm{m}_{\mathrm{SP}}$. The participation of the intestine and the liver in body cholesterol synthesis decreased progressively with the infusion time (intestine : 49.1, 48.8, 43.1 p. 100 ; liver : $13.2,8.6,6.9$ p. 100). Considering that the error in the calculation of the synthesis rates increased with increasing experimental time (see paragraph B), only the results obtained with the shortest experimental time $(3.5 \mathrm{~h})$ are discussed.

D. - The radioactivity of sterols synthesized in situ and remaining in the organ was obtained after subtracting the radioactivity appearing by transfer from the plasma from the total sterol radioactivity. This calculation was correct only if the time-course of plasma cholesterol labeling was the same in the two experiments (labeled acetate infusion and labeled cholesterol infusion). Two types of labeled cholesterol were infused, either by « red-cell » or « plasma » infusion (Chevallier ef al., 1971 ; Giraud-D'Hollander et al., 1976). The ratios of the specific activities of esterified cholesterol to those of free cholesterol in the « red cell » and the «acetate » experiments were similar (17, 32 and 36 p. 100, respectively, instead of 27,38 and 45 p. 100 for the 3 infusion times). On the contrary, the specific activity of esterified plasma cholesterol in the "plasma » experiments exceeded that of free cholesterol. Only the « red-cell » experiments could be used for the transfer correction.

The validity of this correction also implied that the time-course of the specific cholesterol activity in each lipoprotein class would be the same in the two types of experiments because some organs might preferentially metabolize a certain class of lipoproteins ; for example, the adrenals might prefer LDL cholesterol (GiraudD'Hollander et al., 1976) and the liver VLDL (Eisenberg and Rachmilewitz, 1973 ; Eisenberg et al., 1973). This was not a problem in regard to the adrenals since the relative specific activities of LDL cholesterol were not very different in the « acetate » and « red-cell » experiments. The relative specific activities of free and esterified cholesterol of VLDL, however, were respectively 2 and 40 times higher after $3.5 \mathrm{hrs}$ of acetate infusion than after the same time of red cell infusion (Giraud-D'Hollander ef al., 1976). Therefore, in the liver, the contribution of transferred cholesterol was largely underestimated. If, for transfer correction, the specific activity of free cholesterol of the VLDL is used instead of that of the plasma, the participation of the liver 
in body cholesterol synthesis drops to 5 p. 100 at $3.5 \mathrm{~h}$ of infusion, and that of the intestine reaches 55 p. 100.

\section{2. - Rates of cholesterol synthesis.}

The mean rates of cholesterol synthesis in the intact rat were $0.42,0.84$ and $0.79 \mathrm{mg} / \mathrm{h}$ for the three experimental durations. Cholesterol synthesis in organs was reported to depend on circadian variation (Edwards ef al., 1972), with a higher rate at night than during the day. In agreement with these previous observations, the lower value reported here was obtained during the light period (between 9 a.m. and 2 p.m.). Since the light period begins at $8.30 \mathrm{a} . \mathrm{m}$. in our colony, the other two values corresponded to a mean of the rates observed during the circadian rhythm of cholesterol synthesis, and the results were similar to those previously obtained with an isotopic equilibrium method (Chevallier and Lutton, $1966 ; 0.75 \mathrm{mg} / \mathrm{h}$ ) or a balance method (Bloomfield, $1963 ; 0.87 \mathrm{mg} / \mathrm{h}$ ).

Three organs together accounted for about 90 p. 100 of the total cholesterol synthesized : the digestive tract (55-60 p. 100), cutaneous tissue (22 p. 100), and liver (5-10 p. 100). The participation of each of the other organs was between 0.2 and 3 p. 100. In the heart, and especially in the adrenals, cholesterol synthesis was still lower. The cholesterol synthesis rates, previously measured by indirect methods, were 65 and 0.5 p. 100 of the total synthesis in the gut and the brain, respectively (Chevallier and Lutton, 1973 ; Sérougne ef al., 1976). These results are in good agreement with those of the present study (55-60 and 0.58 p. 100).

The liver is generally believed to be the major site of cholesterol synthesis. In in vivo experiments involving hepatectomy (Gould ef al., 1951), the consequences of surgical intervention are sufficient to explain this mistake. The studies of Bricker et al. (1972) using a too-indirect method are not convincing either ; for instance, plasma desmosterol, an indicator of the secreted cholesterol synthesis after triparanol administration, seemed to come mainly from the liver, but the fate of that found in the intestine was unclear.

In some studies, the specific activity of liver cholesterol was higher than that of intestinal cholesterol a short time after acetate injection (Schwenk et al., 1955 ; Van Bruggen ef al., 1953). These data may result from (i) cholesterol contamination by non-sterolic compounds (see Chemical methods) (Chevallier and Rodriques Branco, 1963), (ii) lack of transfer correction, and (iii) abnormally increased hepatic synthesis due to bile acid sequestrants in food (Mathé ef al., 1977). For other authors, the specific activity of liver cholesterol is, as in the present study, considerably lower than that of the intestine cholesterol (Jansen et al., 1970 ; Popjak and Beeckmans, 1950). However, they considered that the liver was the major site of cholesterol synthesis because they overestimated the amount of cholesterol synthesized in the liver and subsequently iransferred to other organs, but they did not measure it. In our experiments, the radioactivity of cholesterol synthesized in the liver was calculated by assuming that the totality of the radioactive cholesterol appearing in all the organs by transfer, was originally synthesized by the liver. This radioactivity was, at the three experimental times, markedly lower than that of the cholesterol appearing in the intestine by synthesis in situ. Such a comparison shows that, even in a situation 
necessarily overestimating cholesterol synthesis in the liver, the intestine behaves as the major organ for cholesterol biosynthesis.

Reçu en avril 1979.

Accepté en mai 1979.

Acknowledgements. - This research was supported by the following grants : INSERM (No 76-1-14517), CEA (No 91.228.L3) and the Fonds Médical. The authors wish to thank Mrs. C. Verneau for her technical assistance.

Résumé. Une méthode de mesure des valeurs absolues de la vitesse de synthèse du cholestérol dans les organes du rat in vivo est décrite. Des rats mâles adultes reçoivent une perfusion intraveineuse d'acétate $1{ }^{14} \mathrm{C}$ de sodium pendant $3,5,6$ et $10 \mathrm{~h}$. La radioactivité spécifique du $\mathrm{CO}_{2}$ expiré est enregistrée en continu pendant l'expérience. Les radioactivités des stérols du plasma, de chacune de ses lipoprotéines et de différents organes sont mesurées. Pour déferminer la radioactivité des stérols réellement synthétisés dans un organe, on tient compte des échanges de cholestérol entre lui ef le plasma. La vitesse de synthèse du cholestérol dans le rat entier et dans chaque organe est calculée à partir des radoiactivités des stérols synthétisés, celle de l'acétyl CoA métabolisé et de la vitesse d'utilisation de l'acétyl CoA. Les résultats montrent que l'intestin est le site majeur de la synthèse du cholestérol (environ 50 p. 100). La participation des autres tissus est moins importante : peau (20 p. 100), foie (moins de 10 p. 100), rein, moelle osseuse, côlon et estomac (2-3 p. 100), tandis que celle de tous les autres organes, particulièrement les surrénales, est très faible.

\section{References}

BLOOMFIELD D. K., 1963. Dynamics of cholesterol metabolism. I-Factors regulating total sterol biosynthesis and accumulation in the rat. Proc. nat. Acad. Sci., 50, 117-124.

BRICKER L. A., WEIS H. J., SIPERSTEIN M. D., 1972, In vivo demonstration of the cholesterol feedback system by means of a desmosterol suppression technique. J. clin. Invest., 51, 197-205.

CHEVALLIER F., 1956. Synthèse du cholestérol chez le rat. Résultats obtenus à l'aide de l'acétate-1 -14C Arch. Sci. phys., 10, 321-336.

CHEVALLIER F., 1967. Dynamics of cholesterol in rats, studied by the isotopic equilibrium method. Adv. Lipid Res., 5, 209-230.

CHEVALLIER F., BRIËRE M., SERELL F., CORNU M., 1962. Mesure en continu de la radioactivité spécifique du gaz carbonique expiratoire d'un animal après administration de composés marqués au carbone 14. Recherche d'équilibres isotopiques. J. Physiol., 54, 701-710.

CHEVALLIER F., D'HOLLANDER F., SIMONNET F., 1968. Renouvellement par synthèse et par transfert du cholestérol libre et estérifié. Grandeur des compartiments chez le rat adulte ef leur répartition tissulaire. Biochim. biophys. Acta, 164, 339-356.

CHEVAlLIER F., D'HOLLANDER F., VAUGHAN M., 1971. Plasma cholesterol ester formation in situ and their transfer into the rat tissues in vivo. Biochim. biophys. Acto, 248, 524-529.

CHEVALLIER F., LUTTON C., 1956. Vitesses des processus de renouvellement du cholestérol contenu dans son espace de transfert chez le rat. I. Méthodes ef résultats obtenus dans le cas d'un régime semi-synthétique témoin. Bull. Soc. Chim. biol., 48, 407-523.

CHEVALLIER F., LUTTON C., 1973. The intestine is the major site of cholesterol synthesis in the rat. Nature New Biol., 242, 61-62.

CHEVALLIER F., MAGOT T., 1975. Evidence of major role of the intestine in cholesterol synthesis in the adult male rat. Experientia, 31, 627-629.

CHEVALLIER F., MATHE D., 1976. Cholesterol biosynthesis. Interest of comparing in vivo and in vitro findings. Paih. Biol., 24, 377-381.

CHEVALLIER F., RODRIQUES BRANCO J., 1963. Synthèse du cholestérol hépatique à partir d'acétate-1-14C chez les rats normaux et porteurs d'une fistule biliaire. Origine du cholestérol biliaire. Rev. fr. Et. clin. biol., 8, 903-909. 
D'HOLLANDER F., CHEVALLIER F., 1969. Estimation qualitative ef quantitative des stérols libres et estérifiés du rat in toto et de 23 de ses tissus ou organes. Biochim. biophys. Acta, 167, 146-162.

DIETSCHY J. M., SIPERSTEIN M. D., 1967. Effect of cholesterol feeding and fasting on sterol synthesis in seventeen tissues of the rat. J. Lipid Res., 8, 97-104.

DIETSCHY J. M., WILSON J. D., 1968 . Cholesterol synthesis in the squirrel monkey : relative rates of synthesis in various tissues and mechanisms of control. J. clin. Invest., 47, 166-174.

EDWARDS P. A., MUROYA H., GOULD R. G., 1972. In vivo demonstration of the circadian rhythme of cholesterol biosynthesis in the liver and intestine of the rat. J. Lipid Res., 13, 396-401.

EISENBERG S., RACHMILEWITZ D., 1973. Metabolism of rat plasma very low density lipoprotein : I. - Fate in circulation of the whole lipoprotein. Biochim. biophys. Acta, 326, 378-390.

EISENBERG S., WINDMUELLER H. G., LEVY R. I., 1973. Metabolic fate of rat and human lipoprotein apoproteins in the rat. J. Lipid Res., 14, 446-458.

FEARS R., MORGAN B., 1976. Studies on the response of cholesterol biogenesis to feeding in rats : evidence against the existence of diurnal rhythms. Biochem. J., 158, 53-60.

GIRAUD-D'HOLLANDER F., MAGOT T., CHEVALLIER F., 1976. In vivo study of free and esterified cholesterol turnover in various tissues of the rat. Biochimie, 58, 855-862.

GOULD R. G., CAMPBELL D. J., TAYLOR C. B., KELLY F. B., WARNER I., DAVIS C. B., 1951. Origin of plasma cholesterol using ${ }^{14} \mathrm{C}$. Fed. Proc., 10, 191-199.

JANSEN G. R., ZANETTI M. E., HUTCHISON C. F., 1970. Synthesis of cholesterol from glucose U.14 $\mathrm{C}$ in the liver and extrahepatic tissues of the mouse. Arch. Biochim. biophys., 138, 433-442.

KRITCHEVSKY D., 1958. Cholesterol, John Wiley and Sons, New York.

MATHÉ D., LUTTON C., RAUTUREAU J., COSTE T., GOUFFIER E., SULPICE J. C., CHEVALLIER F., 1977. Effects of dietary fibers and salt mixtures of cholesterol metabolism in rats. J. Nufr., 107, 466-474.

PASCAUD M., 1963. Oxydation de l'acétate-1 $-{ }^{14} \mathrm{C}$ par le rat et discussion des renouvellements de l'acétate et l'acétyl CoA. Bull. Soc. Chim. biol., 45, 551-559.

POPJAK G., BEECKMANS M. L., 1950. Extrahepatic lipid synthesis. Bioch. J., 47, 233-238.

SCHWENK E., ALEXANDER G. J., FISH C. A., 1955. Studies on the biosynthesis of cholesterol. VIII. - Tissue distribution of cholesterol and presence of precursors in intact animals. Arch. Bioch. Biophys., 58, 37-51.

SÉROUGNE C., LEFĖVRE C., CHEVALLIER F., 1976. Cholesterol transfer between brain and plasma in the rat. A model for the turnover of cerebral cholesterol. Exper. Neurol., 51, 229-240.

SRERE P. A., CHAIKOFF I. L., TREITMAN S. S., BURSTEIN L. S., 1950. The extra-hepatic synthesis of cholesterol. J. biol. Chem., 182, 629-634.

VAN BRUGGEN J. T., HUTCHENS T. T., CLAYCOMB C. K., WEST E. S., 1953. Time course of lipid labeling in the intact mouse and rat. J. biol. Chem., 200, 31-37. 